DOI: https://doi.org/10.18371/fp.3(39).2020.215161

УДК 336.153+352.07:336.14+336.132.11

\title{
ОСОБЛИВОСТІ УПРАВЛІННЯ ДОХОДАМИ ГРОМАД \\ В УМОВАХ ДЕЦЕНТРАЛІЗАЦІЇ
}

\author{
МУЛЕСА Еліна Валеріївна \\ acnipaнm \\ ДВНЗ «Ужггородський національний університет» \\ ORCID ID: http://orcid.org/0000-0002-3373-0152 \\ e-mail:elina13mulesa@ukr.net
}

\begin{abstract}
Анотація. Формування ефективного механізму фінансового забезпечення $\epsilon$ основою для успішного функиіонування територіальних громад та фінансовоі спроможності органів місиевого самоврядування в иілому. $У$ статті проведено аналіз та оцінку структури забезпечення територіальних громад фінансовими ресурсами, а також досліджено особливості їх розподілу та використання в умовах деиентралізаційної реформи. Це дало змогу виокремити наявні проблеми в системі наповнення бюджетів громад та сформувати рекомендації щодо удосконалення їх залучення.
\end{abstract}

Ключові слова. фінансові ресурси, об'єднана територіальна громада, доходи об'єднаної територіальної громади, доходи місиевих бюджетів, органи місиевого самоврядування, державний бюджет, трансферти державного бюджету.

Постановка проблеми. В сучасних умовах демократизації суспільних відносин, децентралізації державної влади та становлення громадянського суспільства, серед проблем формування сучасної системи організації влади на місцях значна увага приділяється реформуванню місцевого самоврядування, як рушійної сили соціального
Аннотация. Формирование эффективного механизма финансового обеспечения является основой для успешного функиионирования территориальных общин и финансовой состоятельности органов местного самоуправления в целом. В статье проведен анализ и оченка структуры обеспечения территориальных общин финансовыми ресурсами, а также исследованы особенности их распределения и использования в условиях децентрализачионной реформы. Это позволило вылделть существующие проблемь в системе наполнения бюджетов общин и сформировать рекомендации по совершенствованию их привлечения.

Ключевые слова. финансовые ресурсы, объединенная территориальная община, доходы объединенной территориальной общины, доходы местных бюджетов, органы местного самоуправления, государственный бюджет, трансферты государственного бюджета.

та економічного розвитку українського суспільства.

Одним із ключових чинників, що сприяють якісним змінам на місцевому рівні, є достатнє фінансове забезпечення об'єднаних територіальних громад (далі - ОТГ). Тому, на сьогоднішній день, новоствореним ОТГ важливо не тільки розуміти механізм фу- 
нкціонування місцевих фінансів, але й вміти аналізувати процеси та явища, що пов'язані з формуванням, розподілом і використанням фінансових ресурсів, використовувати оптимальні методи і засоби, за допомогою яких регулюються та контролюються всі процеси соціально-економічного розвитку територіальної громади. Виходячи 3 цього, дослідження проблемних питань формування, розподілу та використання бюджетних коштів ОТГ України $є$ особливо актуальним в сучасних умовах трансформації органів місцевого самоврядування.

Аналіз останніх досліджень і публікацій. Дослідження особливостей формування та використання фінансових ресурсів місцевих бюджетів ОТГ в умовах децентралізації знайшли своє відображення у працях таких вітчизняних та зарубіжних вчених як: В. Опаріна, М. Бадиди, М. Гончаренко, Т. Гургули, Я. Казюк, Н. Михальчишин, А. Сави та ін. Утім, сучасний стан реформування місцевого самоврядування та фінансової децентралізації в Україні зумовлює потребу в поглибленому вивченні саме проблемних аспектів управління фінансовими ресурсами спроможних територіальних громад 3 метою пошуку методів посилення їх спроможності та самостійності. Саме ці аспекти лежать в основі подальшого дослідження даної тематики.

Метою дослідження $\epsilon$ аналіз та виявлення основних проблем формування та управління фінансовими ресурсами бюджетів територіальних громад в процесі реалізації адміністративнотериторіальної реформи та пошук напрямів щодо їх вирішення.

Виклад основних результатів. Зміна моделі управління в Україні 3 чітким акцентом на посилення ролі місцевого самоврядування в розвитку територій регіонів, а відтак і держави, передбачає запровадження змін в фінансовій сфері та адміністративнотериторіальному устрою країни, результатом яких $\epsilon$ формування фінансово самостійних локальних адміністративно-територіальних одиниць у вигляді ОТГ. На сьогоднішній день, формування спроможних громад в Україні здійснюється 3 урахуванням децентралізаційної реформи, що проводиться урядом. Серед основних іiі питань $є$ зміцнення фінансової основи функціонування територій. Саме тому, вивчення питань розвитку територіальних громад сьогодні неможливе без дослідження їх спроможності, зокрема фінансової, певний рівень якої $\epsilon$, насамперед, результатом бюджетного та податкового реформування, що відбувається в Україні з 2014 року.

Огляд законодавчих змін щодо реалізації створення територіальних громад дозволяє констатувати про забезпечення базових аспектів для формування їх спроможності та самостійності. Зокрема, ОТГ одержали у своє розпорядження додаткові фінансові (60\% ПДФО на власні повноваження, державні медична та освітня субвенціï) та майнові ресурси (право розпоряджатися землями на території об’єднаної громади та ін.). Зроблено перший крок до запровадження повсюдності місцевого самоврядування шляхом внесення змін до Податкового кодексу, що забезпечують право органів місцевого самоврядування встановлювати ставки та пільги по платі за землю не тільки в межах, а й за межами населених пунктів. Крім того, згідно реформи місцевого самоврядування об'єднані громади перейшли на прямі 
міжбюджетні відносини 3 державним бюджетом (до цього прямі відносини мали лише області, райони, міста обласного значення).

Помітно, що в результаті реформи місцевого самоврядування громадам надано досить широке коло повноважень для здійснення впливу на управління фінансами, в тому числі і в частині адміністрування доходів. Однак, незважаючи на це, чимало з утворених ОТГ все ще $\epsilon$ недостатньо спроможними успішно виконувати покладені на них обов'язки і досі зберігають високу залежність від державного бюджету.

Загалом, структура дохідної частини бюджету є характерною та співставною у більшості ОТГ. Згідно Моніторингу процесу децентралізації влади та реформування місцевого самоврядування, проведеного Міністерством розвитку громад та територій України [6], ключову вагу у сукупному обсязі доходів бюджетів ОТГ займають трансферти 3 державного бюджету - в середньому 60-80\%. Другий за питомою вагою блок складається з податкових надходжень, що в середньому становить $15-30 \%$ від загального обсягу доходів. При цьому власні неподаткові надходження складають, як правило, лише близько 5\% від загального обсягу доходів бюджету громади, а доходи від операцій 3 капіталом (продаж комунального майна та земельних ділянок) практично відсутні. Зважаючи на подібну особливість розподілу фінансових ресурсів ОТГ, для визначення їх реальних та потенційних можливостей щодо ефективного соціально-економічного розвитку, доцільним $є$ розглянути кожну з складових дохідної частини бюджетів детальніше.
Найбільшою статтею власних доходів бюджетів ОТГ є податкові надходження - 95\% загального обсягу власних фінансових ресурсів. Однак, враховуючи суттєву залежність обсягу власних доходів ОТГ від зміни норм податкового законодавства на загальнодержавному рівні, ризики їх коливання є досить високими. Найбільшу питому вагу займає податок на доходи фізичних осіб - 65-80\% дохідної частини бюджету. Винятком є громади, на території яких розміщені потужні підприємства 3 великою кількістю найманих працівників: частка доходів від ПДФО перевищує 80\%, (60\% податку на доходи фізичних осіб із заробітної плати надходить до бюджету громади) [3]. Наступними за наповненістю $є$ єдиний податок та плата за землю - в середньому 15-20\% загального обсягу фінансових ресурсів. Щодо розміру екологічного податку та рентної плати, то в середньому вони складають менше $1 \%$ від загального розміру власних надходжень [4].

Важливим $\epsilon$ питання управління місцевими податками та зборами, оскільки впровадження та встановлення їх ставок належить до виключної компетенції місцевих рад і характеризує ефективність роботи органів місцевого самоврядування в цілому. Частка місцевих податків та зборів в загальному обсязі власних надходжень бюджетів об'єднаних територій в середньому складає менше $1 \%$, що вказує на заниження розміру їх ставок, а це є однією із суттєвих проблем формування доходів ОТГ.

Основними причинами такої тенденції на думку експертів $\epsilon$ те, що при визначенні ставок місцевих податків та зборів представники місцевої влади беруть до уваги соціально- 
економічний стан громади, а також існує побоювання, що підвищення ставок призведе до зростання соціального напруження та росту заборгованості з виплат. Крім того, у більшості громад депутати $\epsilon$ представниками бізнесу, або тісно пов'язані 3 ним, а отже, підвищення ставок для них $є$ невигідним.

Відносно доходів від земельного податку та орендної плати за землю, то їх величина прямо пропорційно залежить від достовірності інформації щодо кількості земель, які передані в оренду, та землі, яка знаходиться у власності юридичних та фізичних осіб на території ОТГ. Однак, виявлено, що у більшості випадків ОТГ не забезпечені належними плановокартографічними матеріалами, відповідною землевпорядною та містобудівною документацією [10]. Процес повної інвентаризації земель громадами лише розпочинається, а через обмеженість фінансових ресурсів нормативно-грошова оцінка земель ОТГ є застарілою та потребує оновлення.

Практика свідчить, що незважаючи на те, що структура місцевих податків однакова, надходження від їх сплати в окремих територіальних громадах відрізняються через різну кількість платників єдиного податку, власників нерухомого майна та оподатковуваної його площі, а також різну кількість земельних ресурсів, що перебувають в користуванні юридичних чи фізичних осіб.

У частині адміністрування податкових надходжень бюджетів ОТГ усі повноваження щодо контролю за повнотою нарахування та сплати податків, дотримання інших норм чинного податкового законодавства належать виключно органам Державної податкової служби України (далі - ДПС) згідно Розпорядження Уряду від 21 серпня 2019 р. № 682-р про початок роботи Державної податкової служби України шляхом поділу Державної фіскальної служби.

Співпраця органів місцевого самоврядування та органів ДПС має обмежений характер, а практика створення груп спільного відпрацювання питань повноти надходжень податків та зборів до бюджету територіальної громади за участі представників ДПС не $є$ поширеною. Фактично виконавчі органи ОТГ лише отримують інформацію від органів Казначейства щодо сум сплачених податків, що зараховуються до бюджету відповідної громади, без можливості провести перевірку повноти сплати податкових платежів та в разі виявлення правопорушень притягнути до відповідальності платників податків. Це, в свою чергу, зводить до мінімуму можливість впливу та контролю з боку місцевої влади.

Що стосується неподаткових надходжень, то, незважаючи на достатність повноважень в частині їх адміністрування, в загальному обсязі доходів ОТГ їх частка є незначною і складає $5-7 \%$ [6]. Загалом, у більшості громад вони складаються 3 власних надходжень бюджетних установ (плата за послуги, що надаються ними згідно 3 основною діяльністю, плата за оренду майна таких установ), а також адміністративних зборів та платежів, що найкраще адмініструються в тих ОТГ, де створені Центри надання адміністративних послуг.

До неподаткових надходжень ОТГ також входять кошти від пайової участі у розвитку інфраструктури окремої території та кошти Державного фонду регіонального розвитку. Основною 
причиною низької активності такого виду надходжень є відсутність якісних проектів та низький рівень їх фінансування. Однак з внесенням змін (18 липня 2019 року) до чинного порядку розподілу коштів та збільшенням порогів для потенційних проектів, можливість залучення даного виду надходження знизилася, особливо для сільських ОТГ, оскільки їхня фінансова спроможність $є$ нижчою від міських та селищних ОТГ, а потреба у додаткових ресурсах та залежність від міжбюджетних трансфертів вища [7].

Додатковим видом наповнення бюджетів ОТГ є дохід від здачі в оренду цілісних майнових комплексів та іншого майна, що перебуває у комунальній власності. Однак, під час об'єднання майно територіальних громад передавалось за передавальними актами, проте повна інвентаризація майна громад фактично не проводилась. Тому переважна більшість громад не здають в оренду цілісні майнові комплекси та інше майно, що перебуває у комунальній власності, а у разі наявності такої практики обсяг отриманих коштів є несуттєвим.

Як зазначалося вище, найбільшу частку доходів ОТГ складають міжбюджетні трансферти, тобто кошти, які безпосередньо і безоплатно передають ОТГ з державного бюджету у вигляді дотацій і субвенцій. Ці кошти йдуть на розвиток громади і фінансування освіти, медицини, соціального захисту. Частка переданих 3 державного бюджету коштів здебільшого коливається в межах 65-75\% загальних доходів ОТГ [3], як правило, за рахунок базової дотації та додаткової дотації на здійснення переданих 3 державного бюджету видатків 3 утримання закладів освіти та охорони здоров 'я. Осно- вна відмінність дотацій від субвенцій - відсутність обмежень щодо напрямів їх використання, тимчасом як субвенції мають чітко визначені напрями використання.

Дослідження показали, що із загального обсягу громад у 2020 році три 3 чотирьох ОТГ були дотаційними (тобто отримували базову дотацію 3 державного бюджету), 16\% усіх ОТГ «заможними» (тобто перераховували частину коштів у вигляді реверсної дотації до державного бюджету), а в 9\% ycix ОТГ податкоспроможність бюджетів коливалася в межах середньоукраїнського показника (вони не отримували базової дотації і не перераховували реверсної дотації до державного бюджету) [6].

Найвагомішими за обсягом субвенціями, які виділяють 3 державного бюджету на розвиток ОТГ, були і залишаються: субвенція на будівництво, реконструкції, ремонт і утримання автомобільних доріг загального користування місцевого значення; субвенція на здійснення заходів щодо соціальноекономічного розвитку окремих територій; субвенція на формування інфраструктури ОТГ; субвенція на реалізацію заходів, спрямованих на розвиток системи охорони здоров'я у сільській місцевості, та деякі інші. Крім того, з держбюджету передають місцевим бюджетам освітню та медичну субвенції, субвенцію на виплату допомоги малозабезпеченим сім'ям, субвенцію на надання пільг і житлових субсидій населенню на оплату природного газу та ін. [5].

Однак, виділених коштів 3 державного бюджету виявилося недостатньо для ефективного розвитку в окремих соціальних сферах. У зв'язку зі зростанням заробітної плати працівників 
закладів освіти у 2017 році (на 50$70 \%$ ) [2], у ОТГ виникли проблеми з їх фінансуванням та потреба в залученні додаткових коштів. Також виникли бар'єри в обслуговувані закладів медицини у зв'язку з неточністю проведення медичної реформи на місцевому рівні (відсутність процедур формування госпітальних округів, передачі районних закладів до міст чи ОТГ).

Причиною ситуації недостатності виділених державою коштів на розвиток територій $\epsilon$ те, що темпи формування нових ОТГ випереджають темпи збільшення їх обсягу. Це призводить до нерівності умов розвитку тих ОТГ, які утворено в 2015-2016 роках, i тих, які утворено пізніше.

Досліджуючи питання управління доходами ОТГ в сучасних умовах, варто відмітити, що прямо на наповненість бюджетів громад вплинули зміни внесені до Податкового кодексу щодо підтримки платників податків під час карантину у зв'язку з пандемією Covid-19. Зокрема, з 1 березня по 30 квітня 2020 року не стягувалася плата за землю та не оподатковувалися об'єкти нежитлової нерухомості, в результаті чого доходи місцевих бюджетів скоротилися на обсяг двомісячних надходжень від податку на нерухоме майно та плати за землю. Як наслідок, втрати міських та селищних громад склали 2,6\% доходів бюджетів без трансфертів. Проте найбільш уразливі до нововведень виявилися сільські ОТГ, втрати яких сягнули 3\% [1].

Станом на 1 вересня 2020 року загальна структура власних доходів бюджету для більшості ОТГ залишилася незмінною. При цьому існує високий ризик коливання доходів в результаті змін законодавства на загальнодержавному рівні. Спад ділової активності у зв’язку 3 пандемією Covid-19 може призвести до вивільнення працівників і зниження надходжень від ПДФО та єдиного податку, що є основними бюджетоутворюючими податками. Відповідно, ОТГ повинні будуть знизити свої видатки, що може призвести бюджет до кризового стану, оскільки більшу частину становлять поточні, а не капітальні видатки. Зупиняться проєкти розвитку, відбудуться скорочення працівників апарату та комунальних установ, зменшаться видатки на соціальну інфраструктуру. У зв'язку з цим, першочерговим завданням на рівні держави $є$ розробка компенсаційних механізмів для громад, 3 метою уникнення труднощів при виконанні ними своїх функціональних обов'язків.

Висновки. Підсумовуючи викладений вище матеріал, варто відмітити, що запровадження з початку 2015 року реформою місцевого самоврядування в Україні нової бюджетної моделі, спрямованої на забезпечення фінансової децентралізації, стало одним із переломних моментів в історії української державності. Згідно реформи ОТГ надано широке коло повноважень та можливостей із залучення додаткових джерел надходжень, однак більшість із них й досі важко назвати достатньо спроможними для успішного виконання покладених на них функцій та обов'язків. Дослідження особливостей наповненості бюджетів ОТГ України та специфіки їх фінансового управління дозволили виявити низку проблем та недоліків, які притаманні більшості об'єднаних громад. 3 метою їх усунення, громадам потрібна подальша активна робота у таких напрямках [7], [8]:

- вдосконалення планових документів громади та формування стратегіч- 
ного бачення в її управлінні, що сприяє залученню додаткових джерел надходжень до бюджету, оптимізації видатків та дозволить ефективно розпоряджатися наявними активами;

- проведення роботи місцевої влади для підвищення прозорості та посилення участі населення в управлінні громадою шляхом проведення консультацій з громадськістю про місцеві податки та збори й оприлюднення звітів про враховані та невраховані пропозиції;

- посилити співпрацю з фіскальними органами, створити робочі групи для опрацювання збільшення податкових надходжень, оновлення наявних реєстрів платників податків та зборів, визначення розмірів заборгованості, формування звітів для рад та звернень до ДПС, у разі потреби до правоохоронних органів;

- розробити та затвердити положення про всі місцеві податки і збори, які будуть застосовуватись у відповідному бюджетному періоді на території ОТГ;

- 3 метою збільшення доходів від ПДФО проводити моніторинг щодо наявності відокремлених підрозділів юридичних осіб, зареєстрованих не на території ОТГ, та стежити до якого бюджету ними сплачується відповідний податок;

- здійснити моніторинг суб'єктів підприємницької діяльності, що фактично займаються реалізацією підакцизних товарів (провести звірку з органами ДПС) та тих, що ведуть підприєм- ницьку діяльність на території ОТГ, але не $є$ зареєстрованими в органах ДПС;

- переглянути тарифну політику комунальних підприємств 3 метою збільшення частини прибутку, яку вони повинні відраховувати до місцевого бюджету;

- поглибити роботу з управління активами громади - проведення інвентаризації земельних ресурсів та комунального майна, оновлення нормативногрошової оцінки та розробка системи управління майном, затвердити ставки оренди земельних ділянок в залежності від їхнього функціонального призначення рішенням ради;

- переглянути договори оренди на використання водних об'єктів, видобування корисних копалин, користування цілісними майновими комплексами тощо з метою визначення реальної вартості оренди таких об'єктів;

- запровадити систему адміністрування неподаткових надходжень та в повній мірі використовувати всі можливі джерела наповнення дохідної частини бюджету, у т.ч. кошти субвенції на соціально-економічний розвиток громад, кошти від пайової участі, від оренди комунального майна та цілісних майнових комплексів тощо;

- запровадити систему підвищення кваліфікації управлінських кадрів ОТГ, оскільки практика свідчить про нерозуміння ними навіть базового рівня суті власних завдань та можливостей.

\section{Список використаної літератури:}

1. Відкритий бюджет : веб-сайт. URL : https://openbudget.gov.ua/nationalbudget/incomes (дата звернення: 28.08.2020). 
2. Гончаренко М. В. Механізм формування фінансових ресурсів територіальних громад в умовах децентралізації. Актуальні проблеми державного управління. 2017. №2 (52). URL : http://www.kbuapa.kharkov.ua/e-book/apdu/20172/doc/2/03.pdf (дата звернення: 28.08.2020).

3. Децентралізація : коротко про головне: веб-сайт. URL : http://cost.ua/news/698-detsentralizatsiya-korotko-pro-holovne/ (дата звернення: 28.08.2020).

4. Звіт USAID щодо результатів оцінювання управління фінансами об'єднаних територіальних громад : веб-сайт. URL : https://drive.google.com/file/d/15efX-f0fQ8cxV8L2p23cVNW_DBzRzeNi/view (дата звернення: 28.08.2020).

5. Михальчишин Н. Л. Проблеми фінансового забезпечення територій в умовах фінансової децентралізації. Фінансова політика регіонального розвитку : вітчизняний та зарубіжний досвід: зб. матеріалів Міжнар. наук.-практ. конф. Житомир, 2019. С. 44-47.

6. Моніторинг процесу децентралізації влади та реформування місцевого самоврядування : веб-сайт. URL : https:/decentralization.gov.ua/uploads/ library/file_10.09.2020.pdf (дата звернення: 28.08.2020).

7. Прихований клондайк : як розкрити потенціал бюджетів об'єднаних територіальних громад : веб-сайт. URL : https://voxukraine.org/uk/prihovanij-klondajkyak-rozkriti-potentsial-byudzhetiv-ob-yednanih-teritorialnih-gromad/\#_ftn1 (дата звернення: 28.08.2020).

8. Про внесення змін до Податкового кодексу України та інших законів України щодо підтримки платників податків на період здійснення заходів, спрямованих на запобігання виникненню і поширенню коронавірусної хвороби : Закон України від 29 травня 2020 p. № 17 . URL : https://zakon.rada.gov.ua/laws/show/533-20 (дата звернення 28.08.2020).

9. Результати оцінювання управління фінансами об'єднаних територіальних громад. URL : https://decentralization.gov.ua/uploads/library/file/273/ DOBRE_UA_FMA_Results.pdf_(дата звернення: 28.08.2020).

10. Сава А., Сидорук Б., Волошин Р. Управління земельними ресурсами сільських територій в умовах фінансової децентралізації. Економічний дискурс. 2019. № 3. C. 24-36. 